\title{
Effect of Temperature on Biofuels Production With Catalytic Cracking Process
}

\author{
KA Ridwan ${ }^{1, *}$ Anerasari $\mathrm{M}^{1}$ Taufik Jauhari ${ }^{1}$ Ida Febriana $^{1}$ \\ ${ }^{1}$ Chemical Engineering Department, State Polytechnic of Sriwijaya, South Sumatra, Indonesia \\ *Corresponding author. Email: ka ridwan@polsri.ac.id
}

\begin{abstract}
Biofuel is an alternative fuel that can be produced with organic resources such as vegetable oil and animal fat. One of the items that can be converted into biofuels is waste cooking oil. Waste cooking oil has a long hydrocarbon chain that allows it to be cracked. Biofuels are produced by catalytic cracking process. Catalytic cracking is a process in which complex hydrocarbon fractions are cracked into smaller, more valuable hydrocarbon. In this process natural zeolite is used by its ability on cracking hydrocarbon fractions. This research aims to get optimum condition of converting waste cooking oil to biofuels and to know the effects of temperature and reaction time on its products produced. The amount of raw materials, type of catalyst and amount of catalyst is preferred as controlled variable in this research, whereas temperature and reaction time is preferred as statistical variable. Biofuels are produced by various temperature such as $280^{\circ} \mathrm{C}-320^{\circ} \mathrm{C}$ with reaction time on 60 minutes using natural zeolite catalyst which accelerate the reactions. According to the process that has been done, this research obtained optimum process condition at the highest temperature $320^{\circ} \mathrm{C}$ which reviewed by its yield produced percentage in amount of $9,8147 \%$. Based on various tested parameters including density, viscosity, flash point and GC-MS product produced has required the quality standard.
\end{abstract}

Keywords: Catalytic Cracking, GC-MS, Zeolite

\section{INTRODUCTION}

Biodiesel is a monoalkyl ester of long chain fatty acids contained in vegetable oil or animal fat for use as fuel for diesel engines [1]. It is time to reduce dependence on petroleum by developing alternative energy sources that have changeable properties, one of which is converting vegetable oil into biodiesel. In Indonesia the raw materials that provide biodiesel oil include palm oil, jatropa, used cooking oil, coconut, nyamplung, algae, and others [3]. One of the biofuels that are being intensively developed is biofuel. Biofuel is an alternative fuel that can be produced from organic sources such as vegetable oil and animal fat [4]. Of the several types of materials used as raw material for biodiesel, one of them is used cooking oil which is easy to find and affordable. Utilization of used cooking oil which then processd into biodiesel which is a waste method (used cooking oil) which produces economic value and creates alternative fuels from diesel fuel. Compared to fossil fuels, biofuels have the advantage that they can be produced locally by utilizing available natural sources of oil or fat. The production process will lower the emission level of $\mathrm{CO}$, NO, sulfur and other combustion products and is more easily biodegradable in nature. Biofuel development itself is able to reduce dependence on fossil fuels and its use is more environmentally friendly[5]. Biofuels produced are in the form of biofuels which are grouped into biogasolin, biodiesel and biokerosin. Used cooking oil is used cooking oil which is waste from the frying process. As a result of this process some triglycerides will break down into other compounds, one of which is free fatty acids (FFA). Fatty acids with long hydrocarbon chains can be turned into short-chain hydrocarbons by means of cracking. Like petroleum, used cooking oil also has a triglyceride structure and also contains hydrocarbons [6].

The use of used cooking oil as an abundant and inexpensive raw material is also an effort to reduce environmental pollution caused by unprocessed waste cooking oil before disposal. In this research, natural zeolite catalyst was used. Zeolite is a mineral that is soft and dry easily. Zeolites are generally used as absorbents, catalysts and as a carrier medium in the chemical industry[7]. Natural zeolite has a fairly good ability to break bonds. The choice of zeolite catalyst is based on the ability of zeolites which have high thermal 
stability which can reach temperatures of $400^{\circ} \mathrm{C}$. According to Bukhori (2016), the size of zeolite crystals that are good for use is mostly no more than 10-15 microns, this is due to the smaller size. zeolite, the zeolite pore size will be wider so that the frequency of collisions with cooking oil atoms will be greater and consequently zeolite cracking activity in breaking the chain will be better. This study aims to determine the effect of temperature and reaction time on the biofuels produced and to obtain biofuels based on the characteristics in accordance with SNI 7182: 2015 and SNI 8220: 2017. It is hoped that from the results of this research, knowledge and technology will be obtained that are useful for reducing the problem of waste cooking oil and producing biofuels that can overcome the problem of the energy crisis.

\section{RESEARCH METHODS}

\subsection{Material}

The materials used are wate cooking oil, ziolte catalys, and phenolphthalein indicator.

\subsection{Equipments}

The equipment used are prototype of biodiesel reactor, this simple research activity is carried out continuosly using prototype tanking order to process waste cooking oil to alternative quality biodiesel, beaker glass, analytical balance, viscometer, porcelain cup, erlemeyer, $\mathrm{pH}$ paper, pycnometer, Penksky-Martens falsh point tester.

\subsection{Methods}

The research conducted using a batch reactor prototype for processing used cooking oil into biodiesel. Used cooking oil has several variables, including temperature, processing time, type of catalyst and the amount of catalyst that enters the reactor.

\subsubsection{Catalyst Preparation}

Natural zeolite catalyst is reduced in size by grinding it to $60 \mathrm{mesh}$. Activation of natural zeolites is carried out in two stages, namely physical and chemical activation [4]. Chemical activation is carried out by soaking the zeolite in $1 \mathrm{M} \mathrm{HCl}$ solution for 24 hours then washing it to neutral $\mathrm{pH}$. Physical activation is carried out by heating the zeolite which has been washed in an oven at $130{ }^{\circ} \mathrm{C}$ for 3 hours. After drying, the zeolite was immersed in $2 \mathrm{M} \mathrm{NaOH}$ solution for 24 hours, then washed to neutral $\mathrm{pH}$ and then heated again at $130^{\circ} \mathrm{C}$ for 3 hours. The zeolite sample was then calcined at 300 - $\mathrm{C}$ for 3 hours. Activation is carried out to remove impurities and increase the thermal stability of the catalyst [6]

\subsubsection{Making Biodiesel}

In the cracking process, the reaction takes place in a batch process using 500 grams of used cooking oil with temperature variations $\left(280^{\circ} \mathrm{C}, 290^{\circ} \mathrm{C}, 300^{\circ} \mathrm{C}, 310^{\circ} \mathrm{C}\right.$, and $320^{\circ} \mathrm{C}$ ). With a time of 60 minutes and the use of a catalytic as much as $5 \%$ of the total raw material. The raw materials for used cooking oil and natural zeolite catalyst are placed in the batch reactor and then the ractor is closed tightly to ensure that no gas comes out of the tool gap during the process. The process of cracking (catalyticcracking) is carried out for 60 minutes for a temperature variation of $280^{\circ} \mathrm{C}-320^{\circ} \mathrm{C}$. The resulting biofuel is then analyzed for its physical properties including density, viscosity, and flash point. Analysis of the chemical properties of the product was carried out to determine the composition of its constituent compounds using the Gas chromathographymass spectrometry (GC - MS) Thermo Scientific TracegoldTG - 5MS Column instrument, 40 meters long, $0.25 \mathrm{~mm}$ diameter and $0.25 \mathrm{~mm}$ film thickness. to find out the compounds contained. Density, viscosity and flash point tests were also carried out.

\subsection{Biodiesel Analysis}

\section{2..4.1 PH testing}

PH paperwas prepared, biodiesel samples was pouredinto a beaker, the $\mathrm{pH}$ paper was dippedinto a beaker containing biodiesel samples, the $\mathrm{pH}$ was noted.

\subsubsection{Density testing}

Densty test using the ASTM D-1298 method.

\subsubsection{Flash Point Test}

Flash point test using ASTM D 6450 method

\section{RESULT \& DISCUSSION}

The reaction temperature was varied from 280 ${ }^{\circ} \mathrm{C}-320{ }^{\circ} \mathrm{C}$. Other variables are kept constant at a catalyst concentration of $5 \%$. The reaction product can be seen in Figure 1.

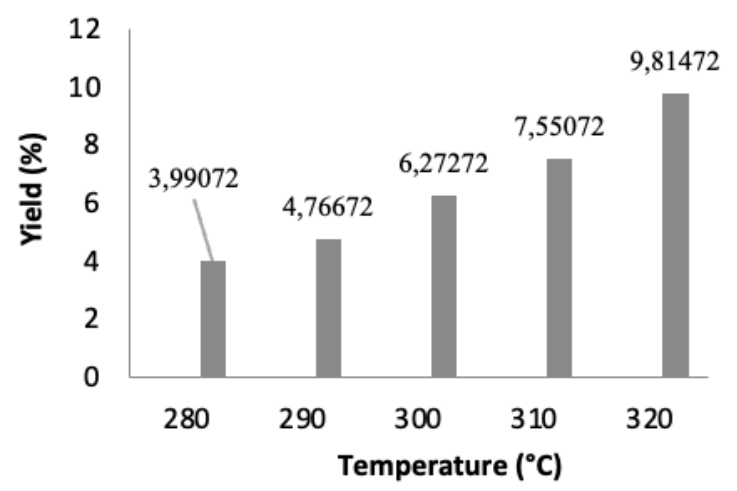

Figure 1. Effect of Temperature on Percent Yield 
The reaction temperature can affect the biofuels produced as shown in Figure 1. The largest percentage yield is produced at a temperature of $320^{\circ} \mathrm{C}$ which is $9.8147 \%$, while the lowest percentage yield is at a temperature of $280{ }^{\circ} \mathrm{C}$ which is $3.9907 \%$. This is because based on the theory, the highest reaction temperature is $9.8147 \%$, while the lowest percentage yield is at $280^{\circ} \mathrm{C}$ which is $3.9907 \%$. large (Shilviadkk, 2014). The increase in temperature that occurs causes the molecules to move faster so that the greater the chance of collision between molecules. The increase in temperature at anaxis causes an increase in the rate of reaction so that the yield percentage obtained will increase.

In certain conditions the temperature is too high, it can reduce the amount of yield produced, this is caused by an increase in temperature which is too high will cause secondary cracking which results in short chain hydrocarbon fraction products in the form of gas that is difficult to condense to the extent to which the air is formed and reduces the amount of biofuel produced (biofuel yield, 2019).

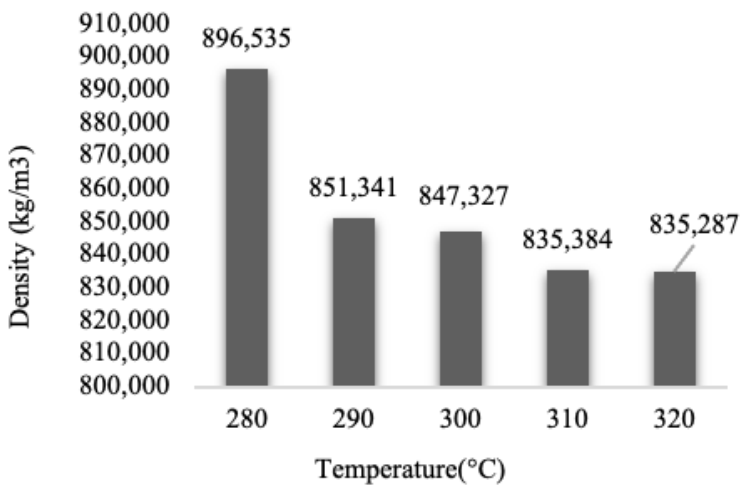

Figure 2. Effect of Temperature on Density

Based on the results obtained, it shows that temperature affects the quality of the biofuel produced. Along with an increase in temperature, the density value obtained decreases as shown in Figure 2. The underlying thing is that the high temperature in the reaction causes the carbon chain to become shorter and fewer double bonds (Shilviadkk, 2014). This means that more and more fatty acids are converted into liquid fuel (Biofuel). The density values obtained at $280^{\circ} \mathrm{C}$ and $290^{\circ} \mathrm{C}$ are $896,535 \mathrm{~kg} / \mathrm{m} 3$ and $851,341 \mathrm{~kg} / \mathrm{m} 3$ in compliance with the SNI 7812: 2015 standard for biodiesel which has a range of $850-890 \mathrm{~kg} / \mathrm{m} 3$. Meanwhile, other density values, namely $847,327 \mathrm{~kg} / \mathrm{m} 3,835,384 \mathrm{~kg} /$ $\mathrm{m} 3$ and $835,287 \mathrm{~kg} / \mathrm{m} 3$ are included in the SNI 8220: 2017 standard for diesel.

\section{CONCLUSION}

Based on the results of research on the production of used cooking oil into liquid fuel (biofuel) through the Catalytic Cracking process that has been carried out, it can be concluded that:

1. The reaction temperature in the production of liquid fuel (biofuel) greatly affects the products produced. The higher the temperature, the more triglyceride chains are converted, meaning that more products are produced.

2. The variation of reaction time can affect product yield, the longer the cracking process time, the more triglyceride chains will be converted.

3. Judging from several test parameters including density, viscosity and flash point, biofuels have been obtained in accordance with the characteristics of SNI 7182-2015 and SNI 8220; 2017.

\section{ACKNOWLEDGMENTS}

We thank to State Poytechnic of Sriwijaya for supporting this Penelitian Penugasan with contract number 3232/PL6.2.1/LT/2020 dated 25 Juni 2020.

\section{REFERENCES}

Febriana I 2019 Study Of The Effect Of Calcium Oxide $(\mathrm{CaO})$ Catalyst Derived From Blood Clam (AnadaraGranosa) And Reaction Time To Quality Of Biodiesel From Waste Cooking Oil.

[2] Aziz I, Muhammad, Nurbayti, Adhani, Permata 2019 Upgrading Crude Biodiesel dari Minyak Goreng Bekas Menggunakan Katalis H-Zeolit. Jurnal Kimia Valensi. Vol. 5, No.1.

[3] Buchori L 2016 Pembuatan Biodiesel Dari Minyak Goreng Bekas Dengan Proses Catalytic Cracking. Semarang : Universitas Diponegoro

[4] Tria Y 2018 CatakyticCracking Minyak Jarak Pagar (JatropaCarcas L) Menggunakan Katalis Zeolit Alam. Jakarta: Universitas Islam Negeri Syarif hidayatullah.

[5] Yanisa, Albertas, Lesmono, Prihandono 2018 Kajian Pengaruh Suhu terhadap Viskositas Minyak goreng sebagai Rancangan Bahan Ajar Petunjuk Praktikum Fisika. Jember: Jurnal Pembelajaran Fisika, Vol.7, No.3.

[6] Gatot, Ida, Yelmida 2014 Perengkahan Katalitik Minyak Goreng Bekas Untuk Produksi Biofuel Menggunakan KatalisIni/ Zeolit. Jurnal Online Mahasiswa UNRI. Vol. 1, No.1. 
[7] Reno, Wiwiek. 2015. Pengaruh Penggunaan Katalis Zeolit Alam Dalam Pirolisis Limbah Plastik Jenih HDPE Menjadi Bahan Bkar Cair Setara Bensin. Jakarta: FT Universitas Muhammadiyah Jakarta

[8] Andrianus 2013 Optimasi Reaksi Perengkahan Minyak Jelantah Menggunakan Katalis Zeolit / Nikel. JKK vol. 2, No. 1.

[9] Arita, Susila 2014 Pembuatan Katalis Heterogen Dari Cangkang Kerang Darah (Anadara Granosa) dan Diaplikasikan Pada Reaksi Transesterifikasi Dari Crude Palm Oil (Universitas Sriwijaya: Palembang)
[10] Aziz, Abdul 2015 Pengaruh pH dan Tegangan Listrik Dalam Elektrolisis Limbah Padat Baja (Slag Eaf) Sebagai Upaya Mereduksi Kandungan Logam Fe Pada Limbah Pada Industri Galvanis (Universitas Islam NegeriWalisongo: Semarang)

[11] Mantovani S A 2017 Pengaruh Jumlah Katalis dan Waktu Reaksi Terhadap Konversi Biodiesel Dari Minyak Jelantah dengan Katalis $\mathrm{CaO}$ Dari KulitTelur(Universitas Muhammadiyah Surakarta) 